\title{
THE POSITION OF THE YOUTH IN POLITICAL PARTICIPATION
}

Melike TEKINDAL ${ }^{1}$

\begin{abstract}
This study aimed to explain youth definition and characteristics of youth, and also evaluate the importance of the youth political participation. Part of the this aim first of all youth definition is given, after that factors and constraints are evaluated on the participation of youth. And also youth needs and importance of media are focused. All this together with the dynamics associated with young people's participation in voting, volunteering, youth programs and organizations are evaluated.
\end{abstract}

Keywords: Social Work, Youth, Political Participation, Youth Political Participation.

${ }^{1}$ Asst. Assoc. Dr., İzmir Katip Çelebi Üniversitesi, Sağlık Bilimleri Fakültesi, Sosyal Hizmet Bölümü, Bölüm Başkanı, Çiğli Ana Kampüsü, 35620, e-posta: meliketunc@yahoo.com.tr/melike.tunc@ikc.edu.tr 


\section{SIYYASAL KATILIMDA GENÇLİĞIN YERINIIN DEĞERLENDİRILMESİ}

\section{Öz}

Bu çalışmada öncelikle gençliğin tanımı ve özellikleri verilerek siyasi katılımda gençliğin önemini değerlendirmek amaçlanmaktadır. Bu amaç kapsamında öncelikle gençlik tanımı yapılmaya çalışılmıştır. Sonrasında çalışmada gençliğin katılımda etkenler ve kısıtlar değerlendirilmektedir. Bunlarla birlikte gençliğin katılım konusundaki ihtiyaçları ve medyanın önemine yer verilmektedir. Bunlarla birlikte gençlerin katılımıyla ilgili dinamikler kapsamında oy verme, gönüllülük, gençlik programları ve örgütlenmeler değerlendirilmektedir.

Anahtar Kelimeler: Sosyal Hizmet, Gençlik, Siyasi Katılım, Gençliğin Siyasi Katılımı. 


\section{The Phenomenon of Youth: Definition and Basic Characteristics}

Human life consists of different periods: babyhood, childhood, youth, adulthood, and old age. Youth is very information for both the individual himself and the society he lives in. Thus, the concepts of "young" and "youth" are very important concepts. The concept of "youth" varies from country to country depending on the average age and cultural factors. The concept of "youth" varies not only from society to society, but from age to age and even from class to class, from stratum to stratum, and from segment to segment.

Youth is a period of change and seeking. This period is melancholic due to the young person's search to find his ego, personality, and identity. $\mathrm{He}$ experiences the pain of exploring himself and changing shell. He can display incoherent attitudes towards his family and environment. The young person that goes in and out of the house as he wishes, does not like anything, and gives sharp responses to moderate warnings is mostly considered to be a problematic person by his family and social environment.

A lot of definitions have been made and various ideas have been put forward about "young" and "youth" so far. However, there is not an absolute consensus on these definitions and ideas. Yet, some definition and ideas are of importance. UNESCO defines youth as the period in which a person develops capabilities and social skills required to be ready for the financial gain and responsibility to be brought by the status of adulthood. Accordingly, youth can be deemed as a special period of life with unique social, economic, psychological, and political characteristics rather than a period limited to determined age boundaries (Erkan, 1985).

Young people want justice to be ensured and inequalities to be eliminated in the society immediately without regard to the facts of life. They have such strong tendencies in this matter that they easily rely on simple solutions and trail behind false leaders to accomplish their goals. Also, they adopt a critical attitude towards all the moral, religious, traditional, and political principles which, they believe, come from their parents. In other words, parents are devalued, and their authority is unconsciously demolished. They generalize 
the demolition of their parents' authority without noticing and thus oppose all the authority figures in the society (Büyükkaragöz, 1987).

They put forward certain abstract principles while contacting with the moral and political values of the society. They mostly believe that these abstract principles have been eliminated by the generations older than them. When this attitude is not canalized well, it can lead to social alienation, which is referred to as "negative identity". This alienation is a result of the split between social values and "himself". This may turn into social explosion any moment. This is because; university students who are both young and have high-level education do not like traditional prescriptions in terms of cultural and political beliefs. Old generations, on the other hand, are more faithful to traditional norms than young people in social control patterns such as family authority and rights, authority, and religion. Differences in attitudes are associated with educational level, too. In general, a good education system is good at directing the youth to modern values (Türkdoğan, 1985).

\section{Youth political participation and the factors influential on it}

There are various ways in which adolescents participate in politics. In democracies, participation is not only about voting. There are some indicators showing the youth's social responsibilities. These indicators are being knowledgeable about the political process and understanding it, thinking techniques, skill of using information technology, participation in media, interaction and discussion skills, and participation in voluntary activities (Schusler and Krasny, 2008: 270).

Youth participation is very important for modern societies as well. This is because; social exclusion and youth participation are considered to be two opposing concepts, and it is emphasized that social inclusion policies cannot be successful unless they ensure youth participation (Edwards, 2008: 17). Social inclusion refers to ensuring the participation of individuals who have difficulty in participating due to reasons such as poverty, lack of education, religion, language, and race in social life. Hence, young people are also considered to be among disadvantageous groups contained in social inclusion (Özer, 2011). 
Research on youth participation shows that most important issues in everyday life are political issues. University students see economic, social and educational issues as important after political issues (Aras, 2007). And also participation takes place in three ways: individual, collective, and official (Pavlidis and Baker, 2010: 27). A similar approach is adopted in the figure below.

Figure 1. Youth Participation Model

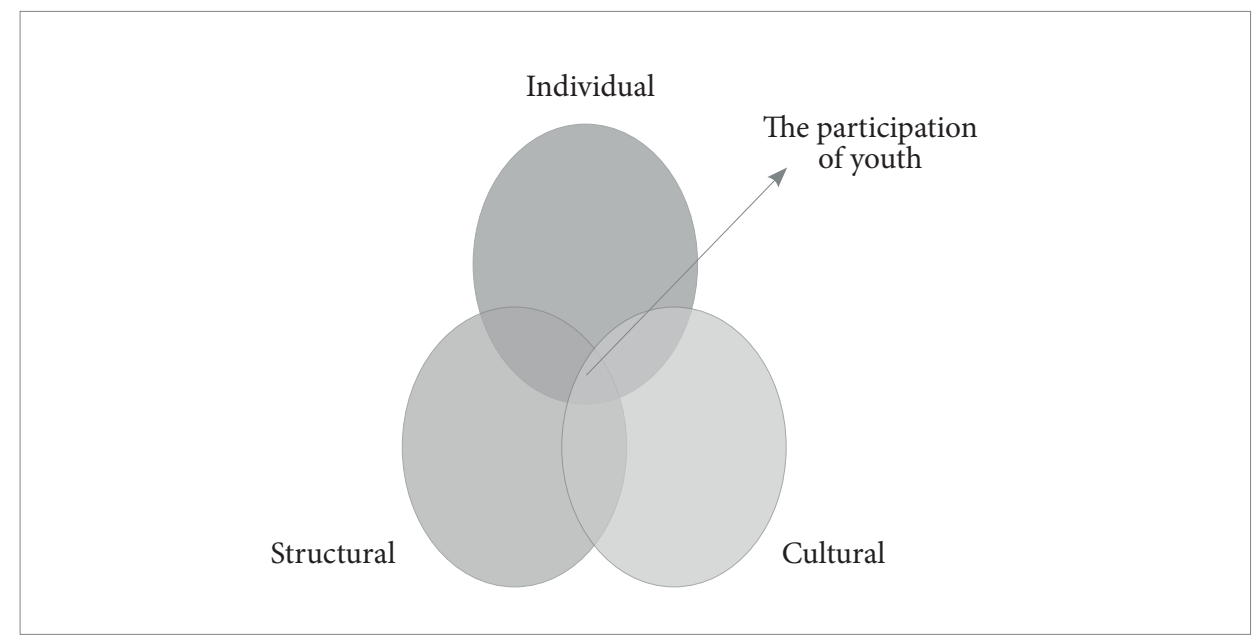

Ref: The International Planned Parenthood Federation (IPPF), 2004: 13.

In the Figure 1, personal knowledge and experiences in practice are evaluated. Organizations' making structural decisions in such a way that youth are also covered is mentioned. Individuals' negative attitudes towards participation, procedures and bureaucracy in the organizations, and cultural values requiring youth to be quiet and calm or disapproving the participation of young women are among the obstacles to participation (The International Planned Parenthood Federation (IPPF), 2004: 13-15). Youth participation in decision-making can change the culture of a person, a society, and an organization. At this point, participation culture emerges. Participation culture is the factor that has the biggest influence on participation, but is most difficult to change as well. All in all, youth participation takes place at the intersection 
of individual, organization, and cultural factors. Participation channels will broaden to the degree that these factors allow youth participation (Özer, 2011).

It should be noted that youth participation varies and differs. While some young people are willing and eager to participate, some others are deprived of support for participation or may not have adequate knowledge about how to participate. Basically, youth's awareness and actual consciousness increase if the decisions concerning them are not taken without regard to them and they organize social actions themselves. Youth participation will increase their experience in participation, enable them to use their political rights, help them democratize, and allow active participation. Not only young people but also adults have to be conscious so that these positive factors are put into practice (Checkoway and Schuster, 2003: 21-30).

It is acknowledged that young people need to be informed above all for participation to be ensured. In other words, young people have to acquire and use decision-making and participation skills to become influential and active citizens (Arches and Fleming, 2006: 85). The research entitled "The Political Awareness of School Leavers" conducted by Straddling in the USA in 1977 concluded that most of the young people of that day had inadequate knowledge on local, national, and international issues (Farthing, 2010: 182). Today's conditions and opportunities to reach the information are much more developed than those days. At the present time, young people are expected to obtain information about participation in various ways. For example, schools are regarded as places where individuals are prepared for life and provided with theoretical knowledge about participation, human rights, and democracy. On the other hand, it is reported that citizenship education given through schools or lifelong learning practices increases level of knowledge about participation, but does not raise interest and action in participation in some countries including England (Print, 2007: 337). Nevertheless, it is stated that schools are the most appropriate place for acquiring knowledge about political participation in a lot of schools and conditions (Fournier and Reuchamps, 2008: 37). Participation is not something to be learned only at schools; on the contrary, it will be strengthened as one takes place in democratic processes (Russell, 1994: 469-493 and Finkel, 2002: 997). In short, schools should not 
be expected to provide young people with a complete education on problems, disorders, or irresponsible behaviors in the society. However, schools must, at least, provide the students with awareness of accountability (UNDP, 2008). Quintelier (2010:149) searched the the possible influence of schools on political participation; and investigated which learning strategies and school characteristics; and also whether there are different effects for different groups of people matter for political participation. Quintelier found that "school students attend does not greatly affect their level of political participation; in other words, most of the difference in political participation can be explained by individual-level characteristics". Secondly "providing young people with political information and with the opportunity to participate encourages them to take a more active role in politics". Last of all "possibly schools do not make a large difference, simply because only small differences in political participation can be observed".

Another factor influential on youth participation is interest. Level of interest in participation and models of participation may vary by gender, educational level, and the place of residence (Gaiser et al., 2010: 428-434). To increase interest in politics and participation among young people, it is necessary to inform them at local and national levels, make politicians accountable about young people and open to representation, and operate participation channels for young people (Molloy et al., 2002: 78). Interest and knowledge are two highly important factors influential on participation. This is because; lack of knowledge and political apathy affect youth participation and are considered to be the basic indicators of low participation rates in elections (Gauthier, 2003: 266).

Young people can raise their levels of interest and knowledge about participation in some ways. Among these ways, media is the most important one. Young people are considered to be the basic consumers of the information produced by media. Youth, who are the consumers of information, deem media both as an actor and as a means of expressing their views. This is, indeed, consistent with the idea of UNESCO that youth should be the active participants of media rather than being passive customers of it (Asthana, 2006: 6). 
Today, young people use information and communication technologies at the highest level. Information moves in the global environment through these technologies. Young people are expected to be always kept in the process so that information to help participation can be obtained (Özer, 2011).

\section{Dynamics Related to Youth Participation}

When participation is mentioned, what comes into mind first is voting in elections. Although voting is an important indicator of democratic life, it is only a starting point for participation. However, though modern democracies aim to increase youth participation, they confront with the decreasing interest of young people in voting, which can be considered to be only a beginner level for participation. In Galson's 2004 research entitled "Civic Education and Political Participation" and Frisco, Muller, and Dodson's 2004 research entitled "Participation in Voluntary Youth-Serving Associations and Early Adult Voting Behavior", which dealt with the voting behaviors of youth in a lot of countries such as the USA, Canada, and the United Kingdom, it was concluded that voting rate falls among young people (Galston, 2004: 263-266; Frisco, 2004: 662-663). It is also reported that young voters in the European Union countries show more interest in national elections in comparison to the elections held for the European Union (Print, 2007: 328-329). On the other hand, Gaiser, De Rijke, and Spannring's research entitled "Youth and Political Participation - Empirical Results for Germany Within a European Context" and Fyfe's research entitled "Civic Education and Political Participation", which dealt with the political behaviors of youth in Germany and Australia, concluded that majority of the young people consider voting to be the most important means of participation (Gaiser et al., 2010: 437; Fyfe, 2009: 39).

To increase participation, it is necessary to attract the attention of youth to politics and diversify the ways of participation. According to the results of the research carried out by Balsano, Phelps, Theokas, J.V. Lerner, and R. M. Lerner in 2009 under the title of "Patterns Of Early Adolescents' Participation in Youth Development Programs Having Positive Youth Development Goals", rise in the quality of local and central youth programs and increase in young people's levels of concentrating on these programs can stop the decrease in participation (Balsano et al., 256). It is reported that those young people who 
take part in a successful youth program gain acquisitions for establishing better relationships with adults, taking responsibility, acquiring new skills, having positive thoughts about others, and participation in social life (Gyamfi et al., 2007: 384; Wood et al., 2009: 295).

Youth programs are effective in creating socio-political awareness besides providing youth with a sense of responsibility and making them understand themselves better (Evans and Prilleltensky, 2007: 690). In Gauthier's research on the social participation of young people entitled "The Inadequacy of Concepts: The Rise of Youth Interest in Civic Participation in Quebec", it is emphasized that youth have adequate participation and interest in social events, but are hesitant about membership to political parties or sympathizing with a political party (Gauthier, 2003:274). Therefore, youth programs should be arranged with a content that will raise youth's interest in politics. All in all, non-implementation of youth programs in a country may have negative effects on both young people and the society as a whole. In this sense, the current programs should be continuous (McFarland and Reuben, 2006: 422). Another factor that is as important as continuity is social cooperation for the success of these programs. At this point, non-centralized choices that take into consideration voluntary participations in administrative decisions and organizational processes are as important as volunteerism-based participatory programs that improve social dialogues (Toprak, 2010: 33).

Young people should be able to speak comfortably and should not avoid speaking in any environment where their opinions are taken and their participation is expected (Faulkner, 2009:99). However, youth may be withdrawn from participation and have hesitations and lack of trust with regard to the consideration of their opinions (Print, 2007: 326-335). On the other hand, young people should not be reprimanded for their opinions in the environments they participate in. Otherwise, they may be withdrawn from participation. The activities involving taking young people's opinions should be continuous, and representatives from civil society and public institutions as well as youth organizations should take part in these activities (GTZ, 2010). In brief, young people should be regarded as one of the means of solving social problems rather than one of the sources of problems (Esen, 2007: 34). 
It is thought that making young people active in the social environment is a supportive factor to ensure self-confidence and participation. In this way, youth should be encouraged to voluntarily participate in youth organizations and voluntary activities that will help to participate in decisions and actions (Checkoway and Schuster, 2003: 21-32). Voluntary activities appear at this point. In Galston's research entitled "Civic Education and Political Participation", it is concluded that voluntary activities increase in the last years of high school period and during university life, but only one-third of youth continue voluntary activities after they get a paid job (Galston, 2004: 263-266).

Organization accompanies young people's intense interest in voluntary activities. Level of organization among young people is higher in industrialized countries in comparison to developing countries (GTZ, 2010).

Youth should reach a stronger position through organization. However, such organization mostly takes place informally or over the Internet. It is clearly seen that organization can effectively be achieved over the Internet. It is reported by Milner in the research entitled "The Informed Political Participation of Young Canadians and Americans" dealing with the US youth's levels of participation and interest that the Internet can be used as an effective means of organization among the young people with a high level of interest though it is not as effective as traditional methods for the 15-25 age group young people with a low level of interest (Milner, 2008: 1-39). Hence, the Internet should not be ignored as it can be an effective means of participation and organization among young people. For instance, it is considerable that young people are organized and protest certain social, political, and economic events over the Internet. This is because; the forums, thought communities, and blogs created over the Internet can direct youth to active participation.

It is accepted that all the communication and information technologies have not only introduced a new dimension to democracy but also turned out to be an opportunity for young people to be active citizens (Farthing,2010: 186). Increase in use of new participation methods by youth will have a highly positive influence on social interaction and active participation (Fyfe, 2009: 40-41). According to the 2009 TurkStat (Turkish Statistical Institute) data, the ratio of individuals below the age of 30 to total population in Turkey is $60.4 \%$. 
Internet usage rate, on the other hand, rose to 34\% in 2009 (Millennium Development Goals Report Turkey, 2010: 61). Accordingly, it can be said that although the ratio of young population is quite high in Turkey, the development of the above-mentioned ways of participation is just at beginner level. Hence, there is a long distance to cover in this matter (Özer, 2011).

Some constraints are mentioned with regard to youth participation. They are mostly about age, economic situation, time, place, and not being ready (Okojie, 2016). Among these factors reducing participation, the main ones are economic constraints, high unemployment, and food insecurity in some countries (Bessant, 2004: 396-397). Therefore, social policy steps should be taken for the youth struggling with economic problems in parallel with participation programs. This lays a burden on local administrations besides the centralized administration (Özer, 2011).

\section{The E-Status of Youth Political Participation}

In today's Turkey, young people have almost no confidence in the traditional political institutions of liberal democracy such as political parties, foundations, and unions and in the capability of these institutions to solve social and political problems. Thus, they have quite low rates of participation in these traditional political institutions (Lüküslü, 2008). Today's youth, who increasingly move away from the representative liberal democratic politics defined based on these political institutions, embark on a quest of new public spheres where they can express themselves.

Questioning the legitimacy of public sphere-private sphere distinction in the Internet-based social groups has also led to questioning distinctions such as individual-community, subject-object, and self-other. Surely, considering the cultural and historical importance and well-established nature of these distinctions, it is not easy to eliminate them. Still, network stands as an alternative technology where individuals can manifest their strengths and avoid the rational domination of the state and institutions (Stone, 1995). All of these mentioned factors offer us the virtual sphere as an alternative public sphere where free and equal individuals can have a direct influence on the democratic process by making negotiations. Online blogs, discussion groups, 
and voting platforms definitely allow democratic participation for participants, though in the virtual sphere. However, this participation takes place in the cyber space to the contrary of conventional participation, physical meetings, and geographically limited spaces (Çebi and Şahin Akıllı, 2011).

Today's youth's lack of interest in the institutions of representative democracy is simply associated with their "political apathy" or "indifference" to social issues. However, voting rates, which reach up to $60 \mathrm{~s} \%$, show that young people are not completely indifferent to domestic politics. Likewise, research conducted on youth through in-depth interview shows that today's youth are aware of problems and get annoyed and even feel sorrow due to them, to the contrary of factoids about them such as "carefree", "easygoing", or "insensitive" (Lüküslü, 2008).

Lüküslü (2011) reports that political sphere is considered to be incapable of solving youth's problems and thus is negatively perceived. Before all, political sphere is defined as a "fusty" order where relationships based on interests play the leading role. Moreover, it is perceived as an area which is difficult to change and has strict rules making it difficult for individuals to make changes. Similarly, all the political organizations (e.g. political parties) are described by young people as "authoritative" groups in which they cannot express themselves comfortably, but only stand as part of a group. However, these do not mean that young people do not have any interest in what is going on and are not affected by it. Indeed, it is possible to see unhappiness and uneasiness due to all what is happening as well as a criticism and a hidden opposition in these feelings. However, such criticism does not appear in traditional politics (Lüküslü, 2009).

Active use of the Internet and computer technology is associated with young generation first. Although Charles Tilly (2004: 98), who reflects on the social movements of the 21 st century, warns that innovations in communication reduce costs of communication, but rigorously exclude those who do not have any access to new communication technologies, thereby leading to inequality, and Pippa Norris (2001) describes "digital divide" as a new form of division, research on the use of information technology emphasizes youth's advantageous position in reaching it (Anduiza, Cantijoch, Gallego, 2009: 
871). In a similar vein, whether the Internet affects political participation or not has been discussed by social scientists much. Though different ideas are put forward in this matter, some researchers argue that a new and different political participation emerges through information technology in this period when young generation do not participate in traditional politics (Della Porta and Mosca, 2005; DiMaggio et al., 2001; Norris, 2002).

Given the fact that today's young generation have been born into these technologies, it can be said that these new youth movements attach importance to the Internet and information technologies in connection with the generation they are part of. It is even impossible to take these movements independent of the Internet and information technologies. Though they also operate in the "real" environment in non-Internet settings, they owe their existence to information technology.

How individuals use media and how often they engage in controversial discussions have social and political consequences. Research has indicated that individuals' patterns of media use have influenced the perceived salience of social issues (Iyengar \& Kinder, 1987; McCombs \& Shaw, 1972), causal attributions (Iyengar, 1991), decisionmaking outcomes (McLeod, Sotirovic, Voakes, Guo, \& Huang, 1998; Sotirovic, 2001), learning (Ferejohn \& Kuklinski, 1990), and political participation (McLeod \& McDonald, 1985).

Sotirovic and Mcleod (2001) states that communication patterns play in political participation. Reading public affairs and diverse discussions have a direct positive impact. While TV entertainment viewing has a direct negative effect on participation. Newspaper public affairs use also affects participation indirectly through more diverse discussions and higher knowledge. And also Public affairs reading mediates the positive effects of postmaterialism, while watching entertainment mediates the negative impact of materialism on participation. The model also demonstrates the positive effects of reading public affairs in newspapers and the negative effects of watching television entertainment on political knowledge and participation. In addition, it shows the various indirect positive effects of newspaper reading operating via reflective integration on participation (Sotirovic and Mcleod, 2001:286). 
This study demonstrates the important role of values in political behavior. Our most important finding is that values influence political participation through shaping individuals' communication behaviors (Sotirovic and Mcleod, 2001:286).

In this regard, establishing communication with the youth requires internalizing the new patterns of communication they have and founding units devoted to them within political formation. Considering the development of technology in the globalizing world, localization of the global, and thus majority of participation, it can be said that communication of the youth in this area proves the existence of an undeniable participation. Therefore, investments to be made in youth can accomplish their goals only with the active participation of the youth.

\section{Conclusion}

Lüküslü (2005:35) demonstrated that the three generations of the Turkish republic, which correspond to the history of modernising Turkey, the changing roles and the changing images of youth have been traced. The emergence of the first generation was closely linked to the birth of Turkey as a nation state, and it has been argued that, in this project, youth figured as both constructed and constructors. The generation of the 1960s and the 1970s has been labelled young "rebels", while the post-1980 generation is conceived of as the first "individualised" generation born into a globalised consumer society. The third generation, the globalisation generation, or individualised youth, is also a worldwide phenomenon. At each of these stages, as was shown above, youth played a dual role, being constructed by the conjuncture of the period and the same time acting as constructors of their time, and carriers of a new culture.

The globalizing world, many evaluations are made on youth political participation by the nature of youth. Youth participation is important because they constitute majority of the population groups and are considered to be future policy-makers. Hence, they are among the population groups that need to be put to the forefront for each political authority.

To conclude, individual, cultural, and structural reasons are influential on youth political participation while age, economic situation, time, place, 
and not being ready are among the factors affecting and constraining youth political participation.

Lopes, Benton and Cleaver (2009:15) suggests that adult models of political participation are helpful in studying young peoples' intentions to participate in England. In particular, there is evidence that English students may be making choices according to the rational actor model. Student efficacy and knowledge may also be important, although the latter's importance may not be as great in the context of young people's participation as it is for adults' engagement.

Adults must be as conscious as young people and play an active role to ensure the active participation of the youth. Knowledge of participation and interest in participation must be raised among the youth. In this regard, media has an undeniable importance. In the globalizing world, access to and use of information bring forward the e-status of political participation. Organizations are mostly in electronic environment in today's world. However, their structures must be evaluated as well.

As fear culture affects participation. It leads to those who are less risky. In addition, fear favors the current political view of power, or it does not appear to be, and it leads to being passive.

The importance of education in youth participation in politics is great. Actors in the education system can play an effective role in genocide political participation in this period, when the age is required to realize itself and the desire for socialization is at the highest level. Particularly in this turnover, the university life is important in determining the genocide political participation preferences. In this sense, support and training for political participation during university education can be effective in making genius the right choice.

Moreover, if we have an authoritarian education system, education institutions can play a negative role in the willingness of young people to political participation because they see political areas as taboo and cautious about discussing political issues. Particularly, it is necessary for educators to support the students, to guide them, to balance the emancipatory practices. The quality of the education given in this sense is also important. Because, if evaluations are not done on current issues, we may have taken the opportunity 
of students to discuss and evaluate the topic. In this sense, young people who are interested in political participation need to be supported within the education system.

It also plays an important role in how the political system works and how it leads the participants. Because liberal, political discourses that do not respect human rights and differences can have a passive effect on young people. They may be afraid and anxious about expressing their own thoughts, acting on their own minds and doing activities. In this case, political participation may decline. Or with this sense of fear, young people can be forced to do the least harm they can. For this reason, educational institutions play an important role in the lives of students. It is expected that these institutions will realize themselves by actively thinking and in objective, non-conflictual discussions. It also aims to perform free, non-coercive, passes through the presence of educators respectful of different ideas and opinions.

When youth political participation is mentioned, what that come into mind first are voting, the effectiveness of youth programs, encouraging to participate in decisions and actions, increasing voluntary activities, and ensuring youth's active participation in these activities. The youth's active participation in the field of organization will also play an active role in their political participation.

Finally, in an age of constitutional reform that aims at encouraging greater democratic participation (Brown 2007; Lopes, Benton and Cleaver 2009:15), it is important to highlight that, from a policy-making perspective, bringing out the personal advantages of participation through citizenship education and other initiatives may be desirable if young people's engagement in civic and political life is to be stimulated. It may also be warranted to take into account young people's ways of engaging with public issues, including their disposition towards rational-actor decisions, when (re-)designing structures for both civic and political participation.

According to the results of Büyüktosunoğlu (2013) study, although there is no significant difference between the students in terms of the level of political interest of the university students, Significant differences were found in the areas such as following the current political process, the most watched programs on 
television, the factors influencing the voting decision and personal interests in shaping political preferences, party leaders, country interests, religious beliefs, attitudes and traditions. The lack of political confidence in university youth in Turkey makes it difficult for students to make healthy and conscious choices.

Socialization is an ongoing process through changing agents at every stage of life. As an important means of socialization in this process, educational institutions are highly influential on young people within the senses of ambivalence in the youth age. Especially the university is an educational institution where students with different political backgrounds study together. Every university or organization has a common culture that develops spontaneously or is developed consciously. This existing common culture affects the individuals within the organization. On the axis of the university's existing culture and ideology, it is inevitable that the identity development and political tendencies of the students are shaped. 


\section{References}

Anduiza, E., Cantijoch, M., Gallego, A. (2009). Political participation and the internet, information. Communication \& Society, 12(6), ss. 860-878.

Aras, H.Ö. (2006). Ankara Üniversitesi Eğitim Bilimleri Fakültesi öğrencilerinin siyasal, ekonomik, toplumsal ve kültürel ilgi alanları. XVI. Ulusal Eğitim Bilimleri Kongresi (5-7 Eylül 2007). Bildiri Özetleri Kitabı.

Arches, J., ve J. Fleming (2006). Young people and social action: youth participation in The United Kingdom and United States. New Directions for Youth Development, 111, ss. 81-90.

Asthana, S. (2006). Innovative practices of youth participation in media, UNESCO (United NationsEducational,ScientificandCulturalOrganization),6,Erişim Tarihi:37.06.2016 http://portal.unesco.org/ci/en/files/22831/11593413569UNESCO_Innovative_ practices.pdf/UNESCO\%2BInnovative\%2Bpractices.pdf.

Balsano, A., E. Phelps, C. Theokas, J.V. Lerner ve R. M. Lerner (2009). Patterns of early adolescents' participation in youth development programs having positive youth development goals. Journal Of Research on Adolescence, 19(2), ss. 249-259.

Bessant, J (2004). Mixed messages: youth participation and democratic practice. Australian Journal of Political Science, 39 (2), ss.387-404.

Brown, G. (2007) . Constitutional reform statement, 3 July (online). Available from:http:// www.pm.gov.uk/output/Page12274.asp [Accessed 1 April 2017].

Büyükkaragöz, S. (1987). Gençlerde törel gelişim ve bu gelişimi etkileyen sebepler. Uluslararası Terörizm ve Gençlik, MEB Yay. Ank.

Büyüktosunoğlu, T. (2013). Selçuk ve Dicle Üniversitesi Öğrencilerinin siyasal katilma davranışları üzerine uygulamalı bir çalışma. Yayınlanmamış Yüksek Lisans Tezi. Selçuk Üniversitesi, Sosyal Bilimler Enstitüsü, Konya.

Checkoway, B. ve K. R. Schuster (2003). Youth participation in community evaluation research. American Journal of Evaluation, 24 (1), ss. 21-33.

Çebi S. ve Y. Şahin Akıllı. (2011). Türkiye’de gençliğin internet üzerinden katılımı özelinde genç siyasallığ 1 ve müzakereci demokrasi. Katılımın e-hali, Gençlerin sanal eylemi. A. T. Aydemir (eds.). Alternatif Bilişim. 198-232

Della Porta, D. ve L. Mosca. (2005). Global-net for global movements? A network of networks for a movement of movements. Journal of Public Policy, 25(1), ss. 165-190. 
DiMaggio, P., Hargittai, E., Neuman, R. ve J. Robinson. (2001). Social implications of the internet. Annual Review of Sociology, 27, ss. 307-336.

Edwards, K (2008). Social inclusion and youth participation: a new deal for Australia's young people? Youth Studies Australia, 27 (2), ss. 11-17.

Erkan, N. (1985). Gençlik ve Demokrasi, Güven Yay., Ank.

Esen, A (2007). Gençliğin yerel siyasete katılımı. Yerel Siyaset, 23, ss. 34-35.

Evans, S. D., ve I. Prilleltensky (2007). Youth and democracy: participation for personal, relational, and collective well-being. Journal of Community Psychology, 35 (6), ss. 681-692.

Farthing, R (2010). The politics of youthful antipolitics: representing the 'issue' of youth participation in politics. Journal of Youth Studies, 13 (2), ss. 181-195.

Faulkner, K.M (2009). youth participation in ongoing public decision-making projects. Childhood: A Global Journal of Child Research, 16 (1), ss.89-104.

Ferejohn, J. ve J. Kuklinski. (1990). Information and democratic processes, Urbana: University of Illinois Press.

Finkel, S.E (2002). Civic education and the mobilization of political participation in developing democracies. The Journal of Politics, 64, ss. 994-1020.

Fournier, B. ve M. Reuchamps. (2008). Youth political interest, political participation, and civic education in French-speaking Belgium. Civic Education and Political Participation Workshop, Université de Montréal: ss.1-47.

Frisco, M.L., C. Muller ve K. Dodson (2004). Participation in voluntary youth-serving associations and early adult voting behavior. Social Science Quarterly, 85 (3), ss.660676.

Fyfe, I (2009). Researching youth political participation in Australia. Youth Studies Australia, 28 (1), ss. 37-45.

Galston, W.A (2004). Civic education and political participation. Political Science and Politics, 37(2), ss. 263-266.

Gaiser, W., J. De Rijke ve R. Spannring (2010). Youth and political participation, empirical results for Germany within a European context. Nordic Journal of Youth Research, 18(4), ss 427-450.

Gauthier, M (2003). The inadequacy of concepts: the rise of youth interest in civic participation in Quebec. Journal of Youth Studies, 6 (3), ss. 265-276. 
GTZ, (2010). E.D.: 05.07.2016 http://www2.gtz.de/dokumente/bib/gtz2010-3224enyouth-structures.pdf

Iyengar, S. ve D.R. Kinder. (1987). News that matters, Chicago: University of Chicago Press.

Iyengar, S. (1991). Is anyone responsible?. How television frames political issues, Chicago: University

Lopes, J., Benton T. ve E. Cleaver. (2009). Young people's intended civic and political participation: does education matter?, Journal of Youth Studies, 12(1), ss. 1-20,

Lüküslü, G.D. (2005). Constructors and constructed: youth as a political actor in modernising Turkey. In Revisiting Youth Political Participation Challenges for Research and Democratic Practice in Europe (Edited Joerg Forbrig). France: Council of Europe Publishing.

Lüküslü, D. (2008). Günümüz Türkiye gençliği: ne kayıp bir kuşak ne de ülkenin aydınlık geleceği, Yentürk, N. Y. Kurtaran ve Nemutlu, G. (2008) Türkiye’de Gençlik Çalışması ve Politikaları içinde, İstanbul Bilgi Üniversitesi Yayınları, İstanbul.

Lüküslü, D. (2009). Türkiye’de “Gençlik Miti”. 1980 Sonrası Türkiye Gençliği, İletişim Yayınları, İstanbul.

Lüküslü, D. (2011). Bilişim teknolojileriyle örgütlenen gençlik hareketleri ve yeni bir siyaset arayışı. Katılımın e-hali, Gençlerin sanal eylemi. A. T. Aydemir (eds.). Alternatif Bilişim. 48-67.

McCombs, M. E. ve Shaw, D.L. (1972). The agenda-setting function of the media. Public Opinion Quarterly, 36, ss. 176-187.

Mcfarland D.A ve J. T. Reuben. (2006). Bowling young: how youth voluntary associations influence adult political participation. American Sociological Review, 71 (3), ss. 401425.

McLeod, J.M., Daily, K., Guo, Z., Eveland, W.P. Jr, Bayer, J., Yang, S. ve H. Wang. (1996). Community integration, local media use and democratic processes. Communication Research, 23, ss. 179-209.

McLeod, J. M. ve D. McDonald. (1985). Beyond simple exposure: Media orientations and their impact on political processes. Communication Research, 12, ss. 3-33.

Millennium Development Goals Report Turkey, Binyıl Kalkınma Hedefleri Raporu Türkiye, (2010). E.D. 27.06.2016 http://www.tr.undp.org/content/turkey/tr/home/ library/mdg/ mdgreportTurkey2010.html 
Milner, H. (2008). The informed political participation of young Canadians and Americans. The Center for Information \& Research on Civic Learning \& Engagement (CIRCLE) Working Paper 60. E.D.: 27.06.2016 http://www.civicyouth.org/Pop Ups/ WorkingPapers/WP60Milner.pdf

Molloy, D., C. White ve N. Hosfield. (2002). Understanding youth participation in local government a qualitative study final report. National Centre for Social Research, ss. 78.

Norris, P. (2002), Democratic Phoenix: reinventing political activism. Cambridge University Press, Cambridge.

Okoj1e, E.E. (2016). E.D.: 05.07.2016 http://www.un.org/esa/socdev/unyin/documents/tc _addis06_1_youth_participation.pdf

Özer, Y. E. (2011). Gençlerin toplumsal yaşama katılımı ve yerel yönetimlerin rolü. Dokuz Eylül Üniversitesi İktisadi ve İdari Bilimler Fakültesi Dergisi, 26 (1), ss.43-65.

Quintelier, E. (2010). The effect of schools on political participation: a multilevel logistic analysis, Research Papers in Education, 25(2), ss. 137-154, DOI: 10.1080/02671520802524810

Pavlidis, A. ve Barker, S. (2010). Who participates? Youth Studies Australia, 29 (1), ss. 27-34.

Print, M. (2007). Citizenship education and youth participation in democracy. British Journal of Educational Studies, 55 (3), ss. 325-345.

Russell, D. (1994). Communists and Democrats: democratic attitudes in the two Germanies. British Journal of Political Science, 24, ss. 469-493.

Schusler, T.M ve M. E. Kasny. (2008). Youth participation in local environmental action: an avenue for science and civic learning? Participation and Learning, ss. 268-284.

Sotirovic, M. ve J.M. McLeod. (2001). Values, communication behavior, and political participation, Political Communication, 18:3, 273-300, DOI: 10.1080/105846001 52400347

Sotirovic, M. (2001). Affective and cognitive processes as mediators of media influences on crime policy preferences. Mass Communication \& Society, 4, ss. 311-329.

Stone, Allucquere Rosanne (Sandy). (1995). The war of desire and technology at the close of the mechanical age. Cambridge: MIT Press.

The International Planned Parenthood Federation (IPPF). (2004). Setting Standards For Youth Participation. E.D.: 27.06.2016 http://www.ippf.org/NR/rdonlyres/ DF423C28-F09C-4912-BE27-6C9970354EE5/0/Setstand_YouthPart.pdf 
Toprak, Z. (2010). Müzakereci demokrasi ve yerel siyasetin demokratik gelişimi. Yerel Yönetimler Yerel Siyaset ve Kentsel Politikalar, Ed. Prof. Dr. Bekir Parlak, Bursa: Dora Yayıncilik, ss. 30-42.

Türkdoğan, O. (1985). Sosyal Şiddet ve Türkiye Gerçeği. Maya Yay. Ankara.

UNDP, (2008). E.D.: 5.07.2016 http://www.undp.org.tr/publicationsdocuments/nhdrtr 2008/nhdr_bp_ali_carkoglu.pdf

Wood, D., R.W. Larson ve J.R. Brown (2009). How adolescents come to see themselves as more responsible through participation in youth programs. Child Development, 80(1), ss. 295-309. 